\title{
Effect of Types and Dosages of Foliar Fertilizers on Morphology and Production of Clitoria ternatea
}

\author{
Sariffudin AN, Umami N*, Suhartanto B, Suwignyo B, Kustantinah \\ Faculty of Animal Science, Gadjah Mada University, Yogyakarta, Indonesia \\ *E-mail: nafiatul.umami@ugm.ac.id \\ (received 21-09-2021; revised 18-10-2021; accepted 27-10-2021)
}

\begin{abstract}
ABSTRAK
Sariffudin AN, Umami N, Suhartanto B, Suwignyo B, Kustantinah. 2021. Pengaruh jenis dan level dosis pupuk daun terhadap morfologi dan produksi Clitoria ternatea. JITV 26(4): 179-186. DOI: http://dx.doi.org/10.14334/jitv.v26i4.2912.

Tujuan penelitian adalah untuk mengetahui pengaruh pemberian jenis dan level dosis pupuk daun terhadap morfologi dan produksi tanaman kembang telang. Penelitian dilaksanakan pada bulan September-November 2020 di Kebun Penelitian Hijauan Makanan Ternak dan Pastura, Fakultas Peternakan, Universitas Gadjah Mada, Yogyakarta. Materi yang digunakan adalah bibit kembang telang, pupuk organik cair (POC) kelinci dan pupuk gandasil D. Penelitian dilakukan menggunakan rancangan acak lengkan (RAL) pola faktorial 2x4. Pupuk daun yang digunakan dalam penelitian adalah pupuk organik cair kelinci dan pupuk gandasil D. Level pupuk daun terdiri dari $0 ; 1,5 ; 3,0$ dan 4,5 g/l/plot. Parameter yang diamati yaitu tinggi tanaman, diameter batang, luas daun, jumlah cabang, produksi segar dan produksi bahan kering tanaman. Data yang diperoleh dianalisis dengan analisis variansi, jika terdapat perbedaan nyata akan diuji lanjut dengan Duncan's New Multiple Test (DMRT) taraf 5\%. Hasil penelitian menunjukkan bahwa pemberian jenis pupuk daun tidak berpengaruh nyata terhadap morfologi dan produksi tanaman kembang telang $(\mathrm{P}>0,05)$, sedangkan level dosis pupuk berpengaruh nyata $(\mathrm{P}<0,05)$ kecuali pada parameter luas daun. Semakin tinggi level dosis pupuk daun yang diberikan diperoleh hasil tinggi tanaman, diameter batang dan jumlah cabang paling maksimal. Perlakuan level dosis pupuk daun 4,5 g/l/plot memperoleh tinggi tanaman, diameter batang dan jumlah cabang tertinggi masing-masing sebesar $160,02 \mathrm{~cm}, 1,14 \mathrm{~cm}$ dan 18,96 cabang. Perlakuan level dosis pupuk 4,5 g/l/plot memberikan produksi segar dan produksi bahan kering tertinggi masing-masing sebesar 19,22 dan 16,75 ton/ha. Kesimpulan dari penelitian ini adalah semakin tinggi dosis pupuk daun yang diberikan, maka beberapa karakter morfologi tanaman, produksi segar dan produksi bahan kering kembang telang juga akan meningkat.
\end{abstract}

Kata Kunci: Clitoria ternatea, Level dosis, Jenis pupuk daun, Morfologi tanaman, Produks

\section{ABSTRACT}

Sariffudin AN, Umami N, Suhartanto B, Suwignyo B, Kustantinah. 2021. Effect of types and dosage level foliar fertilizers on morphology and production of Clitoria ternatea. JITV 26(4): 179-186. DOI: http://dx.doi.org/10.14334/jitv.v26i4.2912.

The aim of this study was to determine effect of types and dose levels of foliar fertilizers on morphology and production of Clitoria ternatea. This study was conducted from September to November 2020 at Forage Research Garden for Animal Feed and Pasture, Faculty of Animal Science, Gadjah Mada University, Yogyakarta. Materials used were Clitoria ternatea, liquid organic fertilizer of rabbit and gandasil D fertilizer. This study was designed in a Completely Randomized Design (CRD) with factorial pattern of $2 \times 4$. The fertilizer dosages were: $0,1.5,3.0$ and $4.5 \mathrm{~g} / \mathrm{l} / \mathrm{plot}$. The parameters measured were plant height, stem diameter, leaf area, number of branches, fresh and dry matter productions. Data were analyzed by the analysis of variance at $5 \%$, with Duncan's Multiple Range Test (DMRT). Results showed that types of foliar fertilizers did not affect morphological characteristics and production of Clitoria ternatea $(\mathrm{P}>0.05)$, but the fertilizer dosages had significant effect $(\mathrm{P}<0.05)$ on morphological characteristics except for leaf area and production of Clitoria ternatea. The higher the dose level of foliar fertilizer the greater the plant height, stem diameter and number of branches. Dosage of $4.5 \mathrm{~g} / \mathrm{l} / \mathrm{plot}$ resulted in the highest plant height, stem diameter and number of branches each 160.02, $1.14 \mathrm{~cm}$ and 18.96 branches, respectively. Dosage of $4.5 \mathrm{~g} / \mathrm{l} / \mathrm{plot}$ gave the highest fresh and dry matter production of 19.22 and 16.75 tons/ha. It is concluded that increasing the dosage level of foliar fertilizer up to $4.5 \mathrm{~g} / \mathrm{l} / \mathrm{plot}$ resulted in an increased quantity measures of several morphological characteristics and production.

Key Words: Clitoria ternatea, Dosage level, Foliar fertilizers, Morphologi, Production

\section{INTRODUCTION}

Main source of feed for ruminants is forage such as grass, legumes and agricultural or plantation wastes
(Saking \& Qomariyah 2017). The main obstacle in providing forage for livestock is its production which is not available throughout the year. This is because the availability of forage is highly dependent on the season. 
Indonesia has two seasons: rainy season and dry season. During the rainy season, production of animal feed will be abundant, on the otherhand during the dry season the production will decrease. Most farmers in Indonesia obtain forage from their own gardens, rice fields, roadsides, forest edges and agricultural residues. Meanwhile, forage obtained from intensive planting/cultivation is very limited, in line with the reduction in agricultural or productive land. Productive and fertile land is usually used to grow food crops that have economic value.

Cultivation of leguminous plants as forage for livestock is potential because these plants are able to adapt to various environmental conditions and have good growth rates. Plant growth is the first indicator that dictates the production of a plant high or low. This is because several growth parameters such as plant height, stem diameter, leaf area and number of branches may have a close relationship with plant biomass production. Factors that affect plant growth and development include internal factors (genes and hormones) and external factors (nutrient content, radiation intensity, water content and temperature).

Butterfly pea (Clitoria ternatea) is one of leguminous plants that has the potential as animal feed because it has high nutrition and is favored by livestock. Clitoria ternatea can grow in various tipes of soil and is resistant to dry conditions and has the best growth when grown in full sun. This plant can still develop during the dry season (Suarna 2005). This plant produce 25-29 tons DM/ha at 42 days of harvest with a protein content of $21,5 \%$ (Sutedi 2013). Butterfly pea cultivation in Indonesia so far has not been widely developed by farmers. Farmers prefer the cultivation of superior grasses, considering that the biomass production of grasses is greater than that of legumes. Butterfly pea is a perennial plant so this plant can be harvested several times a year. To maintain stable production of butterfly pea biomass, an effort is needed by means of fertilization.

Plant biomass production can be increased by utilizing foliar fertilizer. The type of foliar fertilizer that is familiar to the community is gandasil D fertilizer which is used when the plant is in the vegetative phase. Gandasil D fertilizer is a chemical fertilizer, if it is not used properly, it will affect plants. Doses that are too high is poisonous (Nuryani et al. 2019). Therefore, the use of the right dose of fertilizer is an important factor during the process of cultivating feed crops. Another alternative to foliar fertilizers is liquid urine from rabbits as leaf fertilizer. Rabbit liquid fertilizer has advantages over liquid fertilizer from other types of livestock, namely the content of $\mathrm{N}, \mathrm{P}$ and $\mathrm{K}$ is higher, so that the nutrient content of fertilizers can be utilized properly by plants, the provision can be applied through the leaves. The $\mathrm{N}, \mathrm{P}$ and $\mathrm{K}$ contents in liquid organic fertilizer of rabbit were $4,2,8$ and $1,2 \%$, respectively (Sembiring et al. 2017). Applications of foliar fertilizer can be given at the time of tillage or given directly. Direct application of foliar fertilizer to plants or often called the foliar application method has several advantages, including faster absorption of nutrients, thereby increasing plant regrowth and affecting plant productivity. Based on the background, this study was aimed to see effect of type and dose level of foliar fertilizer on morphologi and production of butterfly pea (Clitoria ternatea).

\section{MATERIALS AND METHODS}

\section{Location and time}

This research was carried out at the Forage Research Garden for Animal Feed and Pasture, Faculty of Animal Science, Gadjah Mada University in from September to November 2020. Rainfall in the location during the month of September to November, respectively was 21, 52 and $110 \mathrm{~mm}$ (BPS 2021). Nutrient content of the research soil is shown in Table 1 .

\section{The location}

The tools used consisted of a tillage equipment (hoe, sickle or machete), $5 \mathrm{~m}$ scale measuring instrument to measure plant height, caliper to measure stem diameter, millimeter block paper to measure leaf area, measuring cup and sprayer each scale $1 \mathrm{~L}$ for fertilization, digital scale Camry with an accuracy of $0,01 \mathrm{~g}$ and a hanging- scale WeiHeng with accuracy $1 \mathrm{~g}$ for weighing fertilizer doses and forage production at harvest, plastic bags for forage containers at harvest. Materials used in this study were gandasil D fertilizer, liquid organic fertilizer of rabbit, and 96 pieces of butterfly pea plant.

\section{Methods}

\section{Experimental design}

This study was done based on completely randomized experimental design (CRD) with a factorial pattern of $2 \times 4$. The first factor (A) was the type of foliar fertilizer, consisting of liquid organic fertilizer of rabbit urine and gandazil D fertilizer. The second factor (B) was the dose level, consisting of 0 (without fertilizer), $1.5,3.0$ and $4.5 \mathrm{~g} / \mathrm{l} / \mathrm{plot}$. The treatment combinations were repeated 3 times, so there was a total of 24 plots, with 1 plot consisting of 4 butterfly pea plants.

Fertilization treatment was applied 1 week after the first harvest and was carried out once a week. Fertilizer 
Table 1. The content of nutrients in research soil

\begin{tabular}{lcc}
\hline \hline Nutrient & Unit & Value \\
\hline $\mathrm{pH}$ & - & 6.87 \\
$\mathrm{C}$-organik & $\%$ & 5.49 \\
$\mathrm{~N}$-total & $\%$ & 0.57 \\
$\mathrm{P}_{2} \mathrm{O}_{5}$ & $\mathrm{me} / 100 \mathrm{~g}$ & 18 \\
$\mathrm{~K}_{2} \mathrm{O}$ & $\mathrm{me} / 100 \mathrm{~g}$ & 6 \\
$\mathrm{C} / \mathrm{N}$ & $\mathrm{me} / 100 \mathrm{~g}$ & 9.5 \\
\hline
\end{tabular}

Table 2. The content of nutrients in liquid organic fertilizer of rabbit and gandasil D

\begin{tabular}{lcc}
\hline \hline Nutrient & Liquid organic fertilizer of rabbit $^{* *}$ & ${\left.\text { Gandasil } \mathrm{D}^{* *}\right)}^{*}$ \\
\hline N-Total (\%) & 0.25 & 20 \\
P-Total (\%) & 0.18 & 15 \\
K-Total (\%) & 0.2 & 15 \\
Cu-Total (ppm) & 20 & \\
Fe-Total (ppm) & 1800 & \\
Mn-Total (ppm) & 180 & \\
\hline
\end{tabular}

${ }^{*}$ Result analysis of laboratory Balingtan (2020)

${ }^{* * *}($ Palemba et al. 2013)

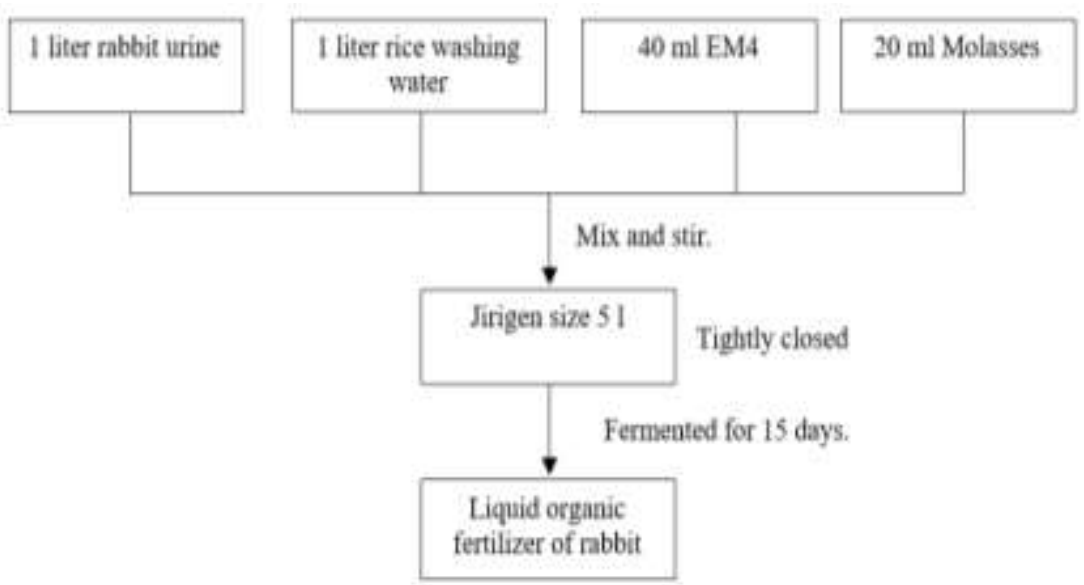

Figure 1. Diagram of making liquid organic fertilizer of rabbit urine

was given by dissolving gandasil D fertilizer, and liquid organic fertilizer of rabbit according to the treatment dose into one liter of water. Fertilizer is given as a foliar application, which means spraying liquid fertilizer directly on plant leaves. Spraying of foliar fertilizer was carried out on the back of the leaf where the stomata are located. Fertilization was carried out at $07.00-09.00$. Plant maintenance includes watering and weeding. Watering is carried out two times a day in the morning and evening. Weeding was done every time there was weeds presented around the main plant. Observation done including: plant height, stem diameter, and number of branches which were carried out once a week, while observations of leaf area were carried out at harvest. Observations began one week after the first harvest. The second harvesting time was carried out after the plants were 45 days old with a cutting limit of $20 \mathrm{~cm}$ from the soil surface. The flow of preparing liquid fertilizer from rabbit urine is shown in Figure 1.

\section{Observed parameters}

Parameters observed included plant height, stem diameter, number of branches, leaf area, fresh forage and dry matter production. Plant height was measured with a measuring instrument from the soil surface to the highest growing point (Tanari \& Sepatondu 2016). The stem diameter measurement was obtained with a 
caliper. Diameter measurement was carried out on the lower stem of the plant about $1 \mathrm{~cm}$ above the base of the stem (Usfunan 2016). The number of branches is obtained by counting the total number of branches on the stem of the plant. Leaf area is obtained by drawing leaves on millimeter paper to form a leaf pattern. Leaf area is estimated based on the number of squares in the leaf pattern. The squares inside the leaf pattern are scored one while the squares crossed by the leaf pattern line are scored half. The formula for leaf area according to (Murdaningsih \& Wae 2012):

$$
L D=n \times L k
$$

where: $\mathrm{LD}=\mathrm{Leaf}$ area, $\mathrm{n}=$ number of square, $\mathrm{Lk}=$ area of each box.

Fresh production was obtained from the second harvest. The second harvest was carried out 45 days after the first harvest. Harvesting was done by leaving the stem $20 \mathrm{~cm}$ above the soil surface (Syamsuddin et al. 2016). Fresh production data for each plot was weighing the harvest yields, while fresh production (ha) was obtained by converting fresh weight $\left(\mathrm{m}^{2}\right)$ to hektare (ha). The dry matter production is obtained by multiplying the fresh production of the plant by the dry matter content of the plant. (Haerudin 2004) stated that total dry matter production can be calculated based on the following formula:

Total DM Prod. $=$ Fresh production $\mathrm{x}$ DM Content (\%)

Dry matter content was measured by (AOAC 2005). The test is carried out at least with 2 repetitions.

\section{Statistical analysis}

Data were analyzed using analysis of variance, if there was a significant difference it was continued by Duncan's New Multiple Range Test (DMRT) at level $5 \%$ performed by IBM SPSS statistic 25.0.

\section{RESULTS AND DISCUSSION}

Result showed that the application of different types of foliar fertilizers did not have a significant effect on morphology and production of butterfly pea (Clitoria ternatea) ( $\mathrm{P}>0.05)$, but the fertilizer dose level did affect significantly $(\mathrm{P}<0.05)$, except for leaf area. This result shows that there is no interaction between the two factors.

\section{Plant height}

Table 3 shows that the type of fertilizer did not significantly affect plant height $(\mathrm{P}>0,05)$ while the dose level did significantly affect $(\mathrm{P}<0,05)$ it. The dose of 4,5 $\mathrm{g} / \mathrm{l} /$ plot wasn't significantly different from the treatment of $3 \mathrm{~g} / \mathrm{l} / \mathrm{plot}$ but significantly different from the treatment of 1,5 and $0 \mathrm{~g} / \mathrm{l} / \mathrm{plot}$, while the dose of 3 $\mathrm{g} / \mathrm{l} / \mathrm{plot}$ was also not different significantly with the treatment of 1,5 and $0 \mathrm{~g} / \mathrm{l} / \mathrm{plot}$. The highest plant height was achieved by a dose of $4,5 \mathrm{~g} / \mathrm{l} / \mathrm{plot}$, which was $160,02 \mathrm{~cm}$. The plant height of the butterfly pea plant was obtained according to research by (Gomez \& Kalamani 2003) who reported that the plant height of Clitoria ternatea could reach $90-162 \mathrm{~cm}$ and was smaller than that of Arnawa et al. (2017) where the height of the butterfly pea ranges from $178,75-220$ $\mathrm{cm}$.

The treatment given was able to increase the height of butterfly pea. The higher the level of fertilizer dose given, the more nutrients available to plants. The availability of these nutrients (especially $\mathrm{N}$ ) can be utilized by plants for growth. The application of foliar fertilizers given by means of foliar application, can also maximize plants in nutrient utilization and fulfillment of nutrient needs so that the rate of photosynthesis can increase. This is in accordance with the opinion of (Ulva et al. 2019) that the increase in the rate of photosynthesis due to the application of foliar fertilizers trigger plant growth, especially the variable of plant height. Butterfly pea height can be influenced by internal and external factors, the most influential external factors are climate and soil factors. According to (Buntoro et al. 2014) that internal and external factors must support each other so that plant growth and development goes well.

\section{Stem diameter}

The type of fertilizer did not affect stem diameter of butterfly pea $(\mathrm{P}>0,05)$, while the dose of foliar fertilizer significantly affect $(\mathrm{P}<0,05)$ stem diameter.

Fertilization treatments of $0,1.5$, and $3 \mathrm{~g} / \mathrm{l} / \mathrm{plot}$ were not significantly different, but all three were significantly different from treatment of $4,5 \mathrm{~g} / \mathrm{l} / \mathrm{plot}$. The highest mean diameter of the stem of the plant was obtained at a dose level of 4,5 g/l/plot which was 1,14 $\mathrm{cm}$. According to (Nugraheni \& Paiman 2011), that an increase in the concentration of rabbit urine given affected the stem diameter of tomato plants. The existence of fertilizer dose of $4,5 \mathrm{~g} / \mathrm{l} / \mathrm{plot}$ is thought to be sufficient for plant for vegetative growth. The application of foliar fertilizers affect the vegetative phase of a plant, because the vegetative phase is an important phase in plant growth.

The increase in stem diameter is due to the process of forming new tissue in plants as a result of plants absorbing available nutrients, especially $\mathrm{P}$. This is in accordance with the opinion of (Satria et al. 2015) that available P stimulate roots to absorb nutrients better so that plants can use it for the formation of new tissues, including increasing stem diameter. The increased 
Table 3. The effect of type and dose level of foliar application on plant height, stem diameter and number of branches of butterfly pea (Clitoria ternatea)

\begin{tabular}{|c|c|c|c|}
\hline \multirow{2}{*}{ Treatment } & \multicolumn{3}{|c|}{ Parameter } \\
\hline & Plant height $(\mathrm{cm})$ & Stem diameter $(\mathrm{cm})$ & Number of branches \\
\hline \multicolumn{4}{|l|}{ Type of fertilizer } \\
\hline Liquid organik fertilizer of rabbit & $127.88 \pm 25.15^{\mathrm{a}}$ & $1.07 \pm 0.05^{\mathrm{a}}$ & $16.68 \pm 3.51^{\mathrm{a}}$ \\
\hline Gandasil D fertilizer & $139.95 \pm 25.00^{\mathrm{a}}$ & $1.09 \pm 0.07^{\mathrm{a}}$ & $16.02 \pm 2.68^{\mathrm{a}}$ \\
\hline \multicolumn{4}{|l|}{ Dose level } \\
\hline $0 \mathrm{~g} / \mathrm{l} / \mathrm{plot}$ & $117.36 \pm 17.73^{\mathrm{a}}$ & $1.04 \pm 0.03^{\mathrm{a}}$ & $13.17 \pm 1.33^{\mathrm{a}}$ \\
\hline $1.5 \mathrm{~g} / \mathrm{l} / \mathrm{plot}$ & $122.74 \pm 23.40^{\mathrm{a}}$ & $1.06 \pm 0.05^{\mathrm{a}}$ & $16.37 \pm 2.32^{\mathrm{b}}$ \\
\hline $3.0 \mathrm{~g} / \mathrm{l} / \mathrm{plot}$ & $135.54 \pm 25.64^{\mathrm{ab}}$ & $1.08 \pm 0.05^{\mathrm{a}}$ & $16.92 \pm 2.25^{\mathrm{b}}$ \\
\hline $4.5 \mathrm{~g} / \mathrm{l} / \mathrm{plot}$ & $160.02 \pm 11.12^{\mathrm{b}}$ & $1.14 \pm 0.05^{\mathrm{b}}$ & $18.96 \pm 3.25^{\mathrm{b}}$ \\
\hline P Value & \multirow{3}{*}{$\begin{array}{l}0.18 \\
0.01\end{array}$} & \multirow{3}{*}{$\begin{array}{l}0.26 \\
0.01\end{array}$} & \multirow{3}{*}{0.54} \\
\hline Type of fertilizer & & & \\
\hline Dose level & & & \\
\hline Interaction & $(-)$ & $(-)$ & $(-)$ \\
\hline
\end{tabular}

${ }^{a, b}$ Different superscripts in the same column showed significant differences $(\mathrm{P}<0,05)$.

diameter of the plant indicates that the plant is growing well. One of the external factors that affect plant growth is nutrition which includes water, minerals and nutrients available in the environment (Qibtyah 2015).

\section{Number of branches}

Result of the analysis showed that the type of fertilizer did not significantly affect number of branches (P> 0,05), but the dose level of foliar fertilizer significantly affected $(\mathrm{P}<0,05)$ number of branches. The treatment of $1,5,3$ and $4,5 \mathrm{~g} / \mathrm{l} / \mathrm{plot}$ weren't significantly different $(\mathrm{P}>0,05)$ but all three were significantly different from the treatment of $0 \mathrm{~g} / \mathrm{l} / \mathrm{plot}$. The average number of branches due to treatment ranged from 16,37 to 18,96 . Results obtained are in accordance with the research of (Arnawa et al. 2017) that the butterfly pea given bio-slurry fertilizer and a predetermined moisture content resulted the number of branches between 13,38-16,31.

The number of branches has a close correlation with plant height. This is because the higher the butterfly pea, the higher the number of branches so it increase the number of leaves of the plant. This is in accordance with the opinion of (Sutopo 2019) that every formation of many branches on a plant is always followed by a large number of leaves formed. This will affect the fresh production of the butterfly pea. Another factor that causes the number of branches obtained in the study to be classified as high, is the cutting of plants during the first harvest. Cutting the plant causes the auxin hormone to accumulate so that the cytokinin hormone to increase and has an impact on the growth of new shoots/branches. (Hariyadi et al. 2011), argues that cutting the main stem of the Jatropha curcas plant increase the number of branches higher than without cutting.

\section{Leaf area}

Effect of giving the type and dose of foliar fertilizers on the leaf area of the plant is presented in Table 3. The leaf area resulted was not significantly different in all treatments, both the leaves on the bottom, middle and top of the plant $(\mathrm{P}>0,05)$. An increase in the level of the dose given has not been able to increase the surface area of the leaf. This could be due to the fact that the level of $\mathrm{N}$ contained was not sufficient to meet the needs of the plant. The $\mathrm{N}$ functions to form leaf green subtances or chlorophyll which plays a very important role in the process of photosynthesis. Adil et al. (2006) stated that the higher the level of $\mathrm{N}$ given (up to maximum limit) will increase the amount of chlorophyll in plants. The increased amount of chlorophyll caused the rate of photosynthesis to increase, so that plants grew optimally (Pramitasari et al. 2016). Another opinion that giving different dose had no effect on leaf area, presumably because the nutrient needs of plants had been fulfilled from the soil (Puspita et al. 2017).

Leaf area had close relationship with plant production. Result showed that leaf area in all treatments had the same average, even though fresh production had different results. This result 
Table 4. Leaf area $\left(\mathrm{cm}^{2}\right)$ of butterfly pea with treatment of type and dose level of foliar fertilizers.

\begin{tabular}{|c|c|c|c|c|c|}
\hline \multirow{2}{*}{ Type of fertilizer } & \multicolumn{4}{|c|}{ Dose level } & \multirow{2}{*}{ Average } \\
\hline & $0 \mathrm{~g} / \mathrm{l} / \mathrm{plot}$ & $1.5 \mathrm{~g} / \mathrm{l} / \mathrm{plot}$ & $3.0 \mathrm{~g} / \mathrm{l} / \mathrm{plot}$ & $4.5 \mathrm{~g} / \mathrm{l} / \mathrm{plot}$ & \\
\hline \multicolumn{6}{|l|}{ Bottom } \\
\hline $\mathrm{A} 1$ & 660 & 6.40 & 6.73 & 6.58 & $6.57 \pm 0.33^{\mathrm{a}}$ \\
\hline $\mathrm{A} 2$ & 5.78 & 5.98 & 6.01 & 5.73 & $5.87 \pm 0.33^{\mathrm{a}}$ \\
\hline Average & $6.19 \pm 0.52^{\mathrm{a}}$ & $6.19 \pm 0.40^{\mathrm{a}}$ & $6.37 \pm 0.44^{\mathrm{a}}$ & $6.15 \pm 0.64^{\mathrm{a}}$ & \\
\hline \multicolumn{6}{|l|}{ Middle } \\
\hline A1 & 15.11 & 14.78 & 14.90 & 15.15 & $14.98 \pm 0.87^{\mathrm{a}}$ \\
\hline $\mathrm{A} 2$ & 15.53 & 15.40 & 15.29 & 16.34 & $15.64 \pm 0.98^{\mathrm{a}}$ \\
\hline Average & $15.32 \pm 1.3^{\mathrm{a}}$ & $15.09 \pm 0.84^{\mathrm{a}}$ & $15.10 \pm 0.7^{\mathrm{a}}$ & $15.75 \pm 1.0^{\mathrm{a}}$ & \\
\hline \multicolumn{6}{|l|}{ Top } \\
\hline $\mathrm{A} 1$ & 13.12 & 12.33 & 13.83 & 15.43 & $13.67 \pm 2.62^{\mathrm{a}}$ \\
\hline $\mathrm{A} 2$ & 12.44 & 14.16 & 13.94 & 15.61 & $14.04 \pm 2.10^{\mathrm{a}}$ \\
\hline Average & $12.78 \pm 2.2^{\mathrm{a}}$ & $13.25 \pm 1.7^{\mathrm{a}}$ & $13.88 \pm 3.2^{\mathrm{a}}$ & $15.52 \pm 1.2^{\mathrm{a}}$ & \\
\hline
\end{tabular}

Table 5. The effect of application of type and dose level of foliar fertilizer on fresh and dry matter produstion of butterfly pea

\begin{tabular}{|c|c|c|c|c|}
\hline \multirow[b]{2}{*}{ Treatment } & \multicolumn{4}{|c|}{ Forage production } \\
\hline & $\begin{array}{c}\text { Fresh } \\
(\mathrm{kg} / \mathrm{plot})\end{array}$ & Fresh (ton/ha) & Dry matter $(\mathrm{kg} / \mathrm{plot})$ & Dry matter (ton/ha) \\
\hline \multicolumn{5}{|l|}{ Type of fertilizer } \\
\hline Liquid organic fertilizer of rabbit & $0.56 \pm 0.08^{\mathrm{a}}$ & $15.49 \pm 2.39^{\mathrm{a}}$ & $0.49 \pm 0.08^{\mathrm{a}}$ & $13.70 \pm 2.09^{\mathrm{a}}$ \\
\hline Gandasil D & $0.64 \pm 0.15^{\mathrm{a}}$ & $17.75 \pm 4.36^{\mathrm{a}}$ & $0.56 \pm 013^{\mathrm{a}}$ & $15.71 \pm 3.65^{\mathrm{a}}$ \\
\hline \multicolumn{5}{|l|}{ Dose level } \\
\hline $0 \mathrm{~g} / \mathrm{l} / \mathrm{plot}$ & $0.49 \pm 0.11^{\mathrm{a}}$ & $13.63 \pm 3.00^{\mathrm{a}}$ & $0.44 \pm 0.09^{\mathrm{a}}$ & $12.21 \pm 2.45^{\mathrm{a}}$ \\
\hline $1.5 \mathrm{~g} / \mathrm{l} / \mathrm{plot}$ & $0.61 \pm 0.15^{\mathrm{ab}}$ & $17.03 \pm 4.05^{\mathrm{ab}}$ & $0.54 \pm 0.13^{\mathrm{ab}}$ & $15.13 \pm 3.46^{\mathrm{ab}}$ \\
\hline $3.0 \mathrm{~g} / 1 / \mathrm{plot}$ & $0.60 \pm 0.10^{\mathrm{ab}}$ & $16.59 \pm 2.89^{\mathrm{ab}}$ & $0.53 \pm 0.11^{\mathrm{ab}}$ & $14.73 \pm 2.98^{\mathrm{ab}}$ \\
\hline $4.5 \mathrm{~g} / \mathrm{l} / \mathrm{plot}$ & $0.69 \pm 0.10^{\mathrm{b}}$ & $19.22 \pm 2.77^{b}$ & $0.60 \pm 0.07^{\mathrm{b}}$ & $16.75 \pm 2.05^{\mathrm{b}}$ \\
\hline \multicolumn{5}{|l|}{$P$ value } \\
\hline Type of fertilizer & 0.09 & 0.09 & 0.08 & 0.08 \\
\hline Dose level & 0.04 & 0.04 & 0.05 & 0.05 \\
\hline Interaction & $(-)$ & $(-)$ & $(-)$ & $(-)$ \\
\hline
\end{tabular}

$\overline{a, b}$ Different superscripts in the same column and row showed significant differences $(\mathrm{P}<0,05)$

indicating that the plant had the same ability in terms of photosynthesis. Leaf area in a plant is very important in the process of photosynthesis. The wider the leaf surface, the better the photosynthesis process because the plant is able to absorb light optimally. (Saragih 2019) added that an increase in leaf area will result in greater assimilation. The ability of leaves to absorb sunlight can decrease if the process of leaf expansion is hampered (Maisura et al. 2015).

\section{Fresh production}

Type of fertilizer didn't significantly affect fresh production of butterfly pea $(\mathrm{P}>0,05)$ while the fertilizer dose did significantly affect $(\mathrm{P}<0,05)$ the production. Results of the analysis showed that a dose $4,5 \mathrm{~g} / \mathrm{l} / \mathrm{plot}$ was not significantly different from the treatment at doses of 1,5 and $3 \mathrm{~g} / \mathrm{l} / \mathrm{plot}(\mathrm{P}>0,05)$ but was significantly different from the treatment at $0 \mathrm{~g} / \mathrm{l} / \mathrm{plot}(\mathrm{P}$ 
$<0,05)$ while between treatments the dose levels of 0 , 1,5 and $3 \mathrm{~g} / \mathrm{l} / \mathrm{plot}$ were not significantly different. This is presumably because the dose level used is still relatively low, affects the number of nutrients received by the plant.

Average production of butterfly pea flower due to treatment ranged from $0,60-0,69 \mathrm{~kg} / \mathrm{plot}$. The higher the fresh weight of the plant, the higher the fresh production. Table 4 also shows that the fresh production of butterfly pea in an area of one hectare due to fertilization treatment got better results than without fertilization, the results ranged from 16,59 to 19,22 tons. The fresh production obtained is higher than that of (Wafi et al. 2020) where the fresh production ranged from 3,7 to 7,25 tons/ha. The fresh production obtained can be influenced by internal factors and external factors. Internal factors include plant physiological conditions while external factors include environmental conditions and the surrounding climate and between these two factors climatic factors most influence production results. According to (Sariffudin et al. 2018) that among climatic factors such as rainfall, duration of sunlight, air humidity and temperature, rainfall is the most dominant factor affecting crop production.

\section{Dry matter production}

Dry matter content was obtained from 100 minus the water content (in \%). The water content of this plant ranged from 9,94 to $14,09 \%$. The treatment did not significantly affect dry matter production $(\mathrm{P}>0,05)$ while the fertilizer dose did significantly affect $(\mathrm{P}<$ $0,05)$ the production. Results of the analysis showed that the treatment at dose of $4,5 \mathrm{~g} / \mathrm{l} / \mathrm{plot}$ wasn't significantly different from the 1,5 and $3 \mathrm{~g} / \mathrm{l} / \mathrm{plot}(\mathrm{P}>$ $0,05)$, but was significantly different from the treatment at $0 \mathrm{~g} / \mathrm{l} / \mathrm{plot}(\mathrm{P}<0.05)$ while between the treatments of $0,1,5$ and $3 \mathrm{~g} / \mathrm{l} / \mathrm{plot}$ were not significantly different. Dry matter production obtained from the treatment ranged from 14,73-16,75 tons/ha. The results obtained are higher than that of (Jelantik et al. 2019) that dry matter production of Clitoria ternatea ranged from 5,18-7.81 tons/ha, but lower than that of (Sutedi 2013) where the dry matter production was $25-38$ tons DM/ha. The dry matter production which was relatively the same in all treatments at the dose levels of foliar fertilizer was probably because the levels of $\mathrm{N}$ content in the liquid fertilizer was not too high so that the requirement of butterfly pea for $\mathrm{N}$ elements was not fulfilled.

The lack of existing nutrient content will have an impact on the inhibition of plant growth and development so that it affect the dry matter content of a butterfly pea plant. This is in accordance with opinion(Keraf et al. 2015), that the higher the dose of $\mathrm{N}$ fertilizer applied, the higher the dry matter production of kume grass. The element of $\mathrm{N}$ functions to compose plant chlorophyll, so that a lack of this element causes the photosynthesis process to be slightly hampered. (Koten et al. 2012) states that the age of harvesting affect the dry matter production of plant, this is because the longer the harvesting time, the longer the opportunity for plants to photosynthesize, resulting in accumulation of photosynthetic material in their plant tissues. The results of photosynthesis which are often called photosynthate will be used by plants to trigger plant growth so that the dry matter production also increases. (Saragih 2019) stated that if the leaf area increased, the assimilate produced would be greater as a result of the increased dry weight of the plant.

\section{CONCLUSION}

It is concluded that the type of foliar fertilizer had no significant effect on the morphological characteristics and production of the butterfly pea plant, while the dose level of foliar fertilizer had a significant effect on several morphological characteristic and production. The higher the dose of foliar fertilizer given the better the plant morphology, the higher fresh and dry matter production of butterfly pea. There was no interaction between the type and the dose level of foliar fertilizers on the morphology and production. With the right dose, liquid organic fertilizer of rabbits and gandasil D fertilizer can be used to increase production of Clitoria ternatea.

\section{REFERENCES}

Adil W, Sunarlim N, Roostika I. 2006. Effect of three different nitrogen fertilizers on several vegetable crops. Biodiversitas J Biol Divers. 7:77-80.

AOAC. 2005. Official methods of analysis of AOAC international. $18^{\text {th }}$ edition. AOAC Int.

Arnawa IW, Suarna IW, Mahardika IG. 2017. Pertumbuhan dan hasil kembang telang (Clitoria ternatea L.) pada berbagai kadar air tanah yang diberikan pupuk bioslurry dengan dosis berbeda. Pastura. 7:41-46.

BPS. 2021. Kecamatan Depok dalam Angka 2021. Yogyakarta (Indones): BPS Kabupaten Sleman.

Buntoro B., Rogomulyo R, Trisnowati S. 2014. Pengaruh takaran pupuk kandang dan intensitas cahaya terhadap pertumbuhan dan hasil temu putih (Curcuma zedoaria L.). Vegetalika. 3:29-39.

Gomez S., Kalamani A. 2003. Butterfly pea (Clitoria ternatea): a nutritive multipurpose forage legume for the tropics - an overview. Pakistan J Nutr. 2:374-379.

Haerudin. 2004. Potensi dan Daya Dukung Limbah Pertanian sebagai Pakan Sapi Potong di Kabupaten Soppeng Sulawesi Selatan. 
Hariyadi, Purwoko B., Raden I. 2011. Pengaruh pemangkasan batang dan cabang primer terhadap laju fotosintesis dan produksi jarak pagar (Jatropha curcas L.). J Agron Indones. 39:205-209.

Jelantik IGN, Nikolaus TT, Penu C., Malelak GEM, Benu I. 2019. Forage production and nutritive value of (Clitoria ternatea) harvested at 60,75 and 90 days after planting. Pastura. 8:76-80.

Keraf FK, Nulik Y, Mullik ML. 2015. Pengaruh pemupukan nitrogen dan umur tanaman terhadap produksi dan kualitas rumput kume (Sorghum plumosum var. timorense). J Peternak Indones. 17:123-130.

Koten B., Soetrisno R., Ngadiyono N, Suwignyo B. 2012. Produksi tanaman sorgum (Sorghum bicolor (L.) Moench) varietas lokal rote sebagai hijauan pakan ruminansia pada umur panen dan dosis pupuk urea yang berbeda. Bul Peternak. 36:150-155.

Maisura, Chozin M., Lubis I, Junaedi A, Ehara H. 2015. Rate of assimilation total and relative growth of drought tolerant rice on paddy system. J Agrium. 12:10-15.

Murdaningsih, Wae YK. 2012. Pengaruh pemberian dosis pupuk $\mathrm{n}$ dan $\mathrm{p}$ terhadap pertumbuhan dan hasil kacang panjang (Vigna sinensis L). Agrica. 5:22-34.

Nugraheni E., Paiman. 2011. Pengaruh konsentrasi dan frekuensi pemberian pupuk urin kelinci terhadap pertumbuhan dan hasil tomat (Lycopersicum esculentum Mill). AgroUPY. 3:30-39.

Nuryani E, Haryono G, Historiawati. 2019. Pengaruh dosis dan saat pemberian pupuk $\mathrm{p}$ terhadap hasil tanaman buncis(Phaseolus vulgaris L.) tipe tegak. J Imu Pertan Trop dan Subtrop. 4:14-17.

Palemba T, Lasut M, Kalangi J, Thomas A. 2013. Aplikasi pupuk daun gandasil d terhadap pertumbuhan bibit jabon merah (Anthocephalus macrophyllus Havil). Cocos. 2:1-10.

Pramitasari H., Wardiyati T, Nawawi M. 2016. The influence of nitrogen fertilizer dosage and plant density level to growwth and yield of kailan plants (Brassica oleraceae L.). J Produksi Tanam. 4:49-56.

Puspita T., Hendarto K, Andalasari T., Widagdo S. 2017. Pengaruh pemberian dosis pupuk npk dan pupuk pelengkap terhadap pertumbuhan dan produksi tanaman sedap malam (Polianthes tuberosa L .). J Agrotek Trop. 5:20-26.

Qibtyah M. 2015. Pengaruh penggunaan konsentrasi pupuk daun gandasil $\mathrm{d}$ dan dosis pupuk guano terhadap pertumbuhan dan produksi tanaman cabai merah
(Capsicum annum L.). Saintis. 7:109-122.

Saking N, Qomariyah N. 2017. The identification of local forages to support the productivity of beef cattle in south sulawesi. Pros Semin Nas Teknol Peternak dan Vet:558-565.

Saragih M. 2019. Hubungan luas daun dengan laju assimilasi bersih. Maj Ilm Methodagro. 5:52-56.

Sariffudin A., Sitompul J., Arsal Z. 2018. Hubungan antara perubahan iklim terhadap produktivitas tanaman padi di lahan sawah kepulauan riau. Pros Semin Nas Adapt dan Mitigasi Perubahan Iklim:599-606.

Satria N, Wardati, Khoiri M. 2015. The giving effect of empty fruit bunch compost and npk fertilizer to growth of agarwood seddling (Aquilaria malaccencis). JOM Faperta. 2:1-14.

Sembiring M., Setyobudi L, Sugito Y. 2017. The effect of rabbit urine fertilizer dosage to growth and yield of some tomato varieties. J Produksi Tanam. 5:132-139.

Suarna I. 2005. Kembang telang (Clitoria ternatea) tanaman pakan dan penutup tanah. Lokakarya Nas Tanam Pakan Ternak.(0361):96-99.

Sutedi E. 2013. Potensi kembang telang (Clitoria ternatea) sebagai tanaman pakan ternak. Wartazoa. 23:51-62.

Sutopo A. 2019. Pengaruh naungan terhadap beberapa karakter morfologi dan fisiologi pada varietas kedelai ceneng. J Citra Widya Edukasi. XI:131-142.

Syamsuddin, Saili T, Hasan A. 2016. Hubungan pemberian pupuk kandang sapi dengan peningkatan kandungan protein dan serat kasar legum Clitoria ternatea sebagai hijauan pakan ternak. J Ilmu dan Teknol Peternak Trop. 3:81-86.

Tanari Y, Sepatondu G. 2016. Kombinasi pemakaian pupuk kandang ayam dan npk terhadap pertumbuhan dan hasil tanaman buncis (Phaseolus vulgaris L.). AgroPet. $13: 28-35$

Ulva D., Supriyono, Pardono. 2019. Efektivitas pupuk daun terhadap pertumbuhan dan hasil kedelai pada sistem tanpa olah tanah. Agrosains. 21:29-33.

Usfunan A. 2016. Pengaruh jenis dan cara aplikasi pupuk kandang terhadap pertumbuhan dan hasil tanaman tomat (Lycopersicum esculentum Mill). Savana Cendana. 1:68-73.

Wafi H., Sowmen S, Aini Q, Yulita E. 2020. Pemanfaatan waretha sebagai bakteri pelarut pospat dan pupuk npk terhadap akar dan produksi Clitoria ternatea di ultisol. Pastura. 10:18-22. 